\title{
Хірургічне лікування ранніх стадій остеоартрозу кульшового суглоба у спортсменів
}

\author{
В. М. Майко, В. Г. Луцишин
}

Вінницька обласна клінічна лікарня ім. М. І. Пирогова, Вінниця, Україна

\begin{abstract}
Резюме. Рассмотрены методы хирургического лечения ранних стадий остеоартроза тазобедренного сустава у спортсменов. Определено, что операции на тазобедренном суставе с помощью артроскопических методов значительно улучшают его функцию и процесс выздоровления.

Ключевые слова: остеоартроз, бедренный сустав, травмы, спортсмены.
\end{abstract}

Summary. The methods of surgical treatment for early stage osteoarthritis of the hip in athletes are discussed. It is ascertained that surgery on the hip joint using arthroscopic techniques significantly improves its function and enhance healing process.

Keywords: osteoarthritis, hip joint, injuries, athletes.

Вважають, що діагностика остеоартрозу (OA) взагалі, і кульшового суглоба (КС) зокрема, відносно проста. 3 цим можна погодитися лише у випадках виразних морфологічних змін субхондральної кістки, коли процес руйнування суглобового хряща досяг значного ступеня і кісткова тканина взяла на себе роль компенсації в навантаженні суглобових поверхонь [2].

Пошук методів візуалізації внутрішньосуглобових утворень важливо продовжувати і вдосконалювати, особливо на ранніх стадіях, коли рентгенологічний метод ще не може об'єктивно оцінити статику i, головне, динаміку структур усередині суглоба [1]. Артроскопія КС в цьому випадку виступає «золотим стандартом», оскільки надає можливість не тільки візуально оцінити статичний стан тканини, а й перевірити внутрішньосуглобову динаміку окремих важливих структур КС [3-5].

Артроскопія КС дозволяє ретельно обстежити практично всі внутрішньосуглобові структури, тобто головку стегнової кістки, вертлюгову западину (В3), синовіальну оболонку, круглу зв'язку, ацетабулярну губу та капсулу суглоба. Все це, зазвичай, здійснюють через маленьке «віконце» в капсулі, крізь яке слід провести інструменти і виконати відповідні дії.

У відділенні травматології й ортопедії Вінницької обласної клінічної лікарні ім. М. І. Пирогова з 2006 р. впроваджено артроскопію КС. За п'ять років у Центрі прооперовано 54 пацієнти, із них 14 - спортсмени-аматори.

Результати усіх прооперованих пацієнтів оцінювали за модифікованою шкалою Харріса, де включено лише оцінку болю (44 бали) і функції (47 балів). Проведений аналіз скарг та даних інструментальних досліджень, зокрема рентгенологічних ознак, дозволив віднести 29 пацієнтів до І стадії ОА за Kellgren-Lawrense, 17 хворих - до ІІ стадії. Вісім осіб не мали рентгенологічних та сонографічних ознак ОА, але у них були клінічні ознаки та скарги, що дали право віднести їх до стану, який за Левенцем називають передартрозом.

Загальновідомим $\epsilon$ той фракт, що кульшовий суглоб під час бігу або стрибків може переносити дуже велику вагу. Важливими $є$ дані зарубіжних авторів, які свідчать, що травми КС у дітей становлять від 10 до $24 \%$, тоді як у дорослих від 5 до $6 \%$ серед усіх ушкоджень суглобів.

Сьогодні близько 60 \% внутрішньо-суглобових ушкоджень КС діагностуються невірно.

Оперативне втручання виконують під спинномозковою анестезією у положенні хворого на спині. Для цього використовують $30^{\circ}$ та $70^{\circ}$ артроскопи 3 типовим набором артроскопічних інструментів, артропомпу, аблятор та шейверну систему.

Важливим моментом під час артроскопії $\epsilon$ можливість та адекватність дистракції КС, що визначається перед хірургічним втручанням під контролем електронно-оптичного перетворювача. Адекватним вважають збільшення суглобової щілини на 1 см (рис. 1).

Введення інструментів у порожнину суглоба виконують з переднього, передньо-латерального, задньо-латерального та середнього передньо-латерального доступів (порталів). 

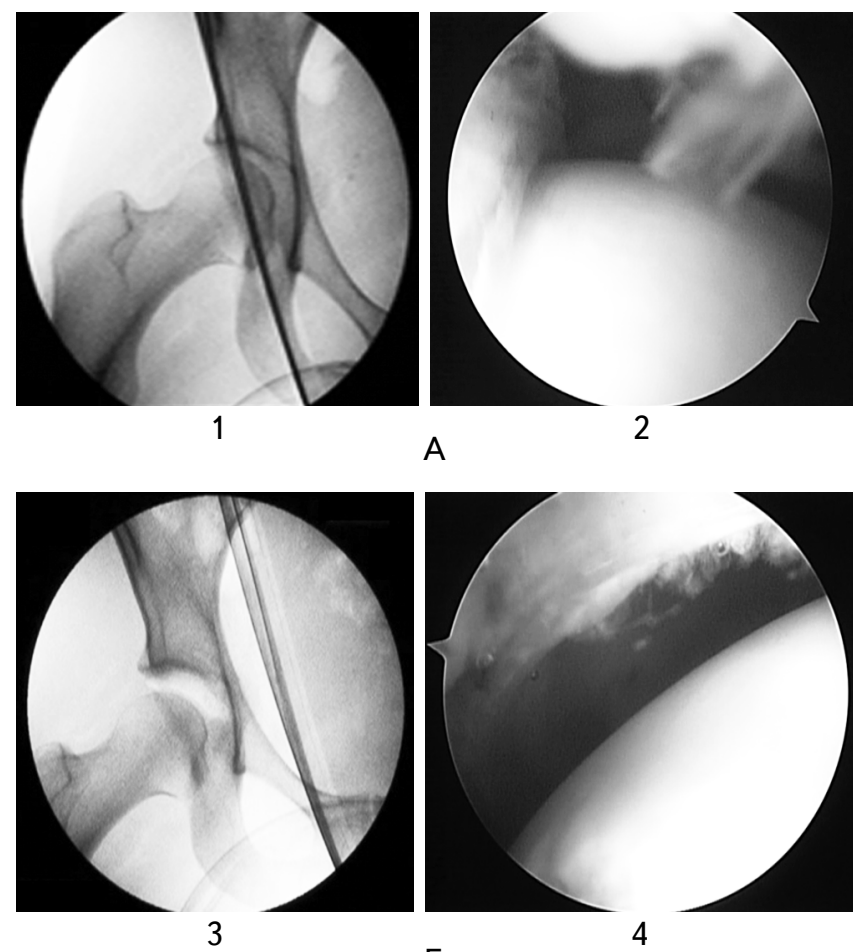

B

Рисунок 1 - Вигляд кульшового суглоба до дистракції (А) та після дистракції (Б) по осі шийки стегнової кістки при фрлуороскопії $(1,3)$ та артроскопії $(2,4)$

Після початку витягування на ортопедичному столі і відкриття суглобової щілини виконують огляд внутрішньо-суглобових елементів.

Левенець В. М. і Пляцко В. В. у 1989 р. розробили свій спосіб визначення центра, що передбачає певні лінії, котрі з'єднують лонний горбик із spina ilaca anterior superior, який ділиться на три рівні частини. В точку, що ділить проксимальну та середню частини, від верхівки великого вертлюга опускають перпендикуляр, який також ділиться на три частини. Точка, що з'єднує внутрішню та середню третини, $\epsilon$ проекцією центра ГСК [1].

Для передопераційного планування артроскопічного втручання і виявлення основних клінічних тестів було проведено апробацію деяких із них.

Дуже важливим $€$ тест на втрату зовнішньої ротації, що $\epsilon$ однією з ознак внутрішньосуглобового розладу. У зв'язку з цим оцінка внутрішньої та зовнішньої ротації, особливо у положенні сидячи, має досить велике значення.

Контроль внутрішньої і зовнішньої ротації комплексний, і тому найменші розбіжності, що відмічаються під час положення сидячи порівняно з розігнутою кінцівкою, викликають необхідність вирішити питання про наявність м'якотканинної аномалії.

Достатня зовнішня ротація має велике значення для певного функціонування КС, і у фразі середнього положення під час нормальної ходьби повинна становити не менше $20^{\circ}$, тоді як показник менше $10^{\circ} \epsilon$ аномальним.

Для безпечного доступу до КС й оптимальної візуалізації усіх внутрішньосуглобових утворень велике значення має точне розташування порталів.

Було визначено, що з усіх ушкоджень суглобового хряща останні частіше зустрічаються у передній та верхній частині ВЗ. Пацієнти з фемороацетабулярним механізмом травми скаржаться на біль у ділянці паху або переднього чи латерального відділу КС. Іноді біль віддає в сідниці. Збільшення сили больового відчуття проявляється під час навантаження на заняттях спортом або під час вставання з положення сидячи чи після тривалого сидіння. У трьох пацієнтів були скарги на «клацання» та обмеження рухів у суглобі, відмічалась легка кульгавість під час ходьби.

Слід звернути увагу на механічні внутрішньосуглобові симптоми та обмеження рухів, «клацання», що вказує на наявність вільних тіл і служить чітким показанням до оперативного втручання.

Як приклад наводимо результати артроскопічного обстеження пацієнтів, які звернулися до ортопедичного відділення Вінницької обласної клінічної лікарні. Д-а С.І., 67 років, поступив у липні 2008 р. зі скаргами на біль у ділянці правого КС. У ході клінічного обстеження у пацієнта виявлено позитивний тест Томаса, тобто на згинальну контрактуру, обмеження ротаційних рухів, а також позитивний тест Мак-Карті (симптом «клацання»), що свідчить про розрив губи або ушкодження суглобового хряща ГСК. Пацієнту запропонували артроскопію, на що він дав згоду.

Артроскопія КС показала, що у хворого наявний вільний хрящовий шматочок із правої ГСК, який переміщався під час пасивних рухів у КС (рис. 2).

Після процедури фрагмент видалено, суглоб промито, амплітуда рухів у суглобі збільшилася.

Пацієнт П-к Д.А., 55 років, звернувся за допомогою у серпні 2009 р. зі скаргами на біль у лівому КС.

У ході артроскопії КС виявлено ушкодження суглобового хряща ГСК III стадії за R. Outerbridge, що свідчить про хронічний перебіг (більше 6 міс.), розміром понад $1 \mathrm{~cm}^{2} 3$ дефектом хрящового покриття, розташованим на передньоверхній частині головки розміром $8 \times 2$ мм, 3 пухкими краями, дном якого $€$ субхондральна кістка. Краї хрящового дефекту мають клаптеподібний вигляд.

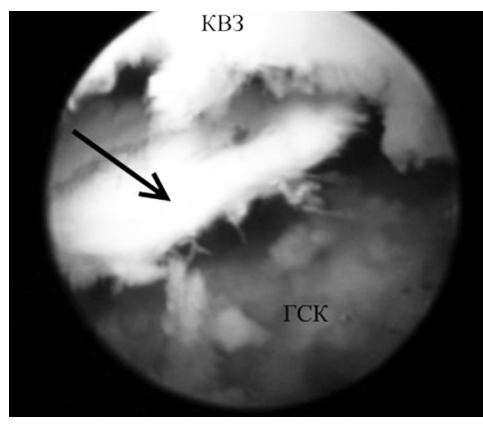

Рисунок 2 - Спостереження через передньо-латеральний портал: повне травматичне клаптеве відшарування фррагмента суглобового хряща ГСК 
Краї ушкодженого хряща та дно дефекту (субхондральну пластинку) оброблено шейвером та буром (рис. 3).

Артроскопічне видалення нестабільних фррагментів хряща 3 абразивною хондропластикою або стимуляцією хондрогенезу методом мікропереломів субхондральної пластинки у поєднанні з лікуванням іншої взаємопов'язаної патології забезпечує багатообіцяючі результати лікування хрящових ушкоджень КС.

Слід зазначити, що для визначення істинної ефрективності та надійності цих методів необхідні тривалі спостереження.

Ушкодження ацетабулярної губи КС - найпоширеніша патологія, що зустрічається під час артроскопії. Було відмічено, що розриви губи КС зустрічаються у $90 \%$ випадків і частіше у передній частині та пов'язані з різкими ротаційними рухами стегна. Ця патологія спостерігається у спортсменів-професіоналів таких видів спорту, як футбол та гімнастика.

Найчастіше пацієнти скаржаться на біль у ділянці паху (92 \%), а типовою причиною вважають забій суглоба, що виявлено у $95 \%$ хворих. Більшість пацієнтів пов'язують біль із фрізичною активністю, меншість - із перевантаженням. Деякі пацієнти відмічають зниження діапазону рухів у КС.

Як приклад наводимо спостереження пацієнтів, яким було виконано артроскопію кульшового суглоба після клінічного та рентгенологічного обстеження.

Пацієнт Б-й В.М., 38 років, спортсмен-аматор, займається фрутболом, зазнавав неодноразових травм, у тому числі падіння на бік, прямі удари на ділянку вертлюга. Звернувся зі скаргами на біль у правому КС, кульгавість, неможливість виконувати згинання в суглобі, приведення та внутрішню ротацію. Після клінічного обстеження було встановлено попередній діагноз: ушкодження ацетабулярної хрящової губи.

Під час проведення артроскопії КС виявлено частковий клаптеподібний розрив ацетабулярної губи і проведено її парціальну резекцію шейвером (рис. 4).

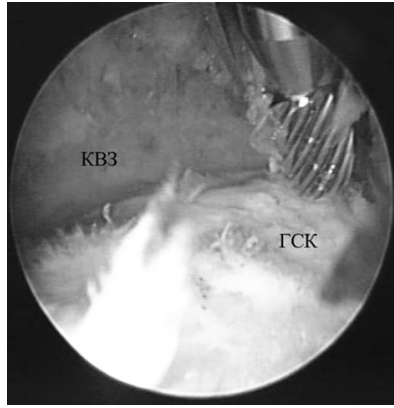

Рисунок 3 - Вигляд обробленої субхондральної пластинки

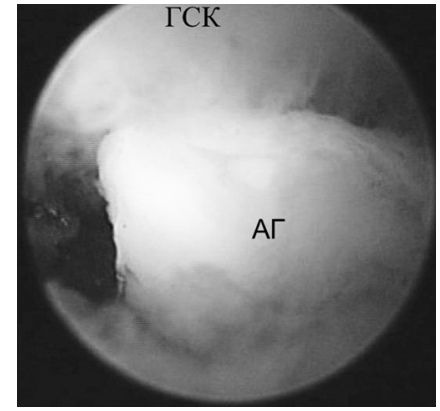

Рисунок 4 - Клаптеподібний розрив ацетабулярної губи
Пацієнт Б-н О.А., 34 роки, поступила до травматологічного відділення обласної лікарні у вересні 2009 р. після дорожньо-транспортної пригоди.

При госпіталізації клінічно визначались кульгавість, біль у паху, позитивні симптоми Мак-Карті, періодичне «клацання» при розгинанні, внутрішній ротації, відведенні та розгинанні стегна.

Під час артроскопії (рис. 5) виявлено повний розрив ацетабулярної губи КС із защемленням ушкодженої частини у суглобовій щілині $(\mathrm{a}$, б). Після розтягнення суглобових кінців ушкоджену частину губи відсічено, край оброблено шейвером, суглоб промитий (в).

Результати артроскопічної санації у пацієнтів групи спостереження в строки від одного до трьох років після операції були наступні: у 40 випадках загострення були відсутні або мали місце не більше одного разу на рік, що тривали менше 1,5 міс. і були ліквідовані консервативним лікуванням із переведенням у стадію ремісії. В ці самі строки зберігалися попередній рівень компенсації і якості життя та початкова стадія ОА.

У семи випадках перебіг ОА був менш сприятливим. Відмічалося більше одного загострення протягом року, або воно продовжувалося більше 1,5 міс. та погано піддавалося консервативному лікуванню.

Перед операцією середня оцінка КС за шкалою Харріса становила 70,5 бала, через один

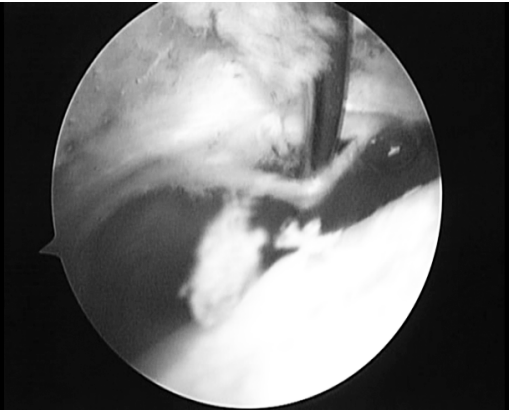

a

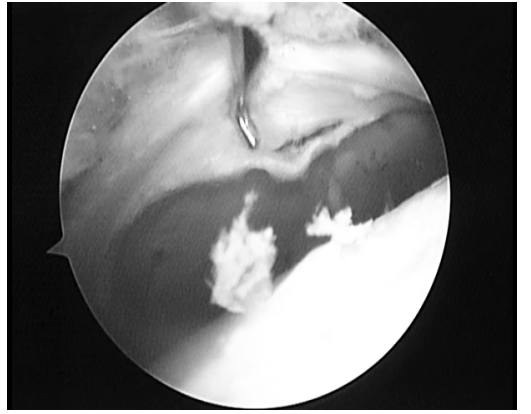

б

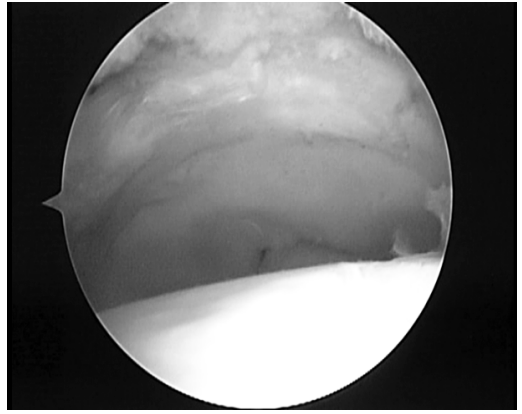

B

Рисунок 5 - Повний розрив ацетабулярної губи кульшового суглоба: а, б - із защемленням ушкодженої частини у суглобовій щілині; в - після розтягнення суглобових кінців 
рік у 40 випадках - у середньому 81,3 бала, через два і три роки у обстежених пацієнтів вона становила відповідно 79,4 і 78,7 бала. Тобто досягнуті добрий і задовільний результати залишилися стабільними. У восьми випадках результат був вище 90 балів, тобто вважався відмінним. Імпіджмент-синдром був ліквідований у всіх випадках і не рецидивував у жодного

\section{Література}

1. ЛеВенец В. Н. Артроскопия / В. Н. Левенец, В. В. Пляцко. - К.: Наук. думка, 1991. - С. 210.

2. Левенець В. М. Діагностика ранніх доклінічних фоорм остеоартрозу у спортсменів / В. М. Левенець, В. М. Майко, Л. Е. Осадча, Т. В. Коломієць // Спорт. медицина. 2011. - № 1-2. - С. 104-109.

3. Майко В. М. Опыт артроскопического дебридмента коленного сустава у больных гонартрозом / В. М. Майко, В. Г. Луцишин // Спорт. медицина. - 2007. - № 3. C. $53-56$.

4. Страфрун С. С. Лікування остеоартрозу кульшового суглоба з використанням артроскопічних технологій / С. С. Страфрун, В. М. Майко, Р. О. Сергієнко, В. Г. Луцишин / / Вісник ортопедії, травматології та протезування. 2011. - № 1. - C. 11-14.

5. Maiko V. Measurement of the femoral antetorsion angle in patients with restricted rotation in hip joint by ultrasound method / V. Maiko, A. Vovchenco, O. Maiko // ISMUS, International Society for Musculoskeletal Ultrasound 10th Congress. - Cluj-Napoca, 2010. - 23-25 September. - 25 p. пацієнта протягом всього строку спостереження.

Висновок: операції на кульшовому суглобі за допомогою артроскопічних методів дозволяють зменшити тенденцію дегенеративно-дистрофрічного процесу до хронізації і прогресування, в термін до п'яти років покращують його функцію в середньому за шкалою Харріса на 13-14 балів.

\section{References}

1. Levenets V. N. Arthroscopy / V. N. Levenets, V. V. Pliatsko. - Kyiv: Naukova dumka, 1991. - P. 210.

2. Levenets V. M. Diagnosis of early preclinical osteoarthritis in athletes / V. M. Levenets, V. M. Maiko, L. E. Osadcha, T. V. Kolomiyets // Sports medicine. - 2011. - № 1-2. P. 104-109.

3. Maiko V. M. Experience of arthroscopic debridement of the knee joint in patients with gonarthrosis / V. M. Maiko, V. G. Lutsishin // Sports medicine. - 2007. - № 3. P. 53-56.

4. Strafun S. S. Treatment of osteoarthritis of the hip joint using arthroscopic technologies / S. S. Strafun, V. M. Maiko, R. A. Sergienko, V. G. Lutsyshyn // Visnyk ortopedii, travmatologii i protezuvannia. - 2011. - № 1. - P. 11-14.

5. Maiko $V$. Measurement of the femoral antetorsion angle in patients with restricted rotation in hip joint by ultrasound method / V. Maiko, A. Vovchenco, O. Maiko // ISMUS, International Society for Musculoskeletal Ultrasound 10th Congress. - Cluj-Napoca, 2010. - 23-25 September. $-25 \mathrm{p}$. 